\title{
PENGARUH SENAM JANTUNG SEHAT TERHADAP NILAI TEKANAN DARAH PADA LANSIA PENDERITA HIPERTENSI
}

\author{
ANTRI ARIANI, MELIANA FUJI LESTARI, ANDRIA PRAGHOLAPATI
}

UNIVERSITAS BHAKTI KENCANA
UNIVERSITAS PENDIDIKAN INDONESIA

EMAIL: Antri.ariani@bku.ac.id

\begin{abstract}
The disease is often experienced by the elderly in Indonesian according to Department of Health Houshold Survey on Health is hypertension with the incidence by $15,7 \%$. Based on data from Department Health Office in Sumedang district, The highest cases of non-communicable diseases is hypertension by $29,6 \%$. This reseach as a purpose determine the effect of a healthy heart gymnastics on the value of blood pressure in elderly hypertensive patients in Community Health Center DTP Jatinangor 2015. This type of research that is quasi experiment with an approach one group pre and postest design. The reseach population by 24 respondents specified by purposive sampling techniques. The reseach results revealed an average value of systolic blood pressure for 3 weeks before a healthy heart gymnastics is $142,8 \mathrm{mmHg}$ and diastolic $94,2 \mathrm{mmHg}$, while after being given for 3 weeks healthy heart gymnastics the average value of systolic blood pressure was $129.6 \mathrm{mmHg}$ and $86.3 \mathrm{mmHg}$ diastolic. Test results paired T-Test obtainable $\rho$ value $0.000<0.05$ for systolic and diastolic blood pressure, means there is healthy heart gymnastics influence on the value of blood pressure in elderly hypertensive patients in Community Health Center DTP Jatinangor 2015.
\end{abstract}

Keywords : Elderly, Hypertensive, Healthy Heart Gymnastics

\section{PENDAHULUAN}

Penuaan adalah suatu proses alami yang tidak dapat dihindari. Penyakit yang erat hubungannnya dengan proses menua salah satunya yaitu gangguan sirkulasi darah atau kardiovaskuler, diantaranya hipertensi (Azizah, 2011). Penyakit yang paling sering dialami oleh lansia di Indonesia menurut Departement of Health Houshold Survey on Health yang dikutip dalam Azizah (2011) yaitu hipertensi dengan angka kejadian sebesar $15,7 \%$ dan berada pada peringkat pertama.

Hasil survey kesehatan rumah tangga tahun 2009 di Indonesia menunjukkan prevalensi tekanan darah tinggi cukup tinggi, yaitu 83 per 1000 anggota rumah tangga, dimana sekitar 0,15\%, dari jumlah tersebut di derita oleh lansia. Angka kejadian hipertensi di Indonesia paling banyak terjadi di daerah Jawa Barat yaitu mencapai 47,8\%. Prevalensi di kalangan lansia cukup tinggi, yaitu sekitar $40 \%$ dengan kematian sekitar $50 \%$ di atas umur 60 tahun (Akhyar, 2009).

Berdasarkan data dari Dinas Kesehatan Kabupaten Sumedang, kasus tertinggi penyakit tidak menular tahun 2014 adalah kelompok penyakit jantung dan pembuluh darah, salah satunya adalah penyakit hipertensi sebesar 29,6\% yang sebagian besar diderita oleh lansia sebanyak 59,3\%, jumlah tersebut lebih tinggi dibanding dengan jumlah keseluruhan hipertensi di kabupaten/kota lain di Jawa Barat, (Dinkes, 2014). 
Terapi hipertensi secara umum ada 2 yaitu dapat dilakukan secara farmakologi dan nonfarmakologi. Penatalaksanaan farmakologi adalah pengobatan yang menggunakan obat-obatan modern. Penatalaksanaan non-farmakologi merupakan pengobatan tanpa obat-obatan yaitu dengan pola yang sehat, istirahat yang cukup, berhenti merokok, mengelola stres, melakukan aktivitas fisik seperti senam atau olahraga, seperti : melakukan senam jantung sehat (Susilo \& Wulandari, 2011).

Hasil penelitian oleh Cerika dalam Tesis (2008) menunjukan bahwa latihan Senam Jantung Sehat dengan intensitas sedang (70-80\%), dengan lama latihan 20-40 menit sekali latihan, dan frekuensi latihan 2-3 kali seminggu, mampu menurunkan secara signifikan tekanan darah pada penderita hipertensi dengan penurunan sebesar 3,346\% (sistolik) dan 4,273\% (diastolik). Sedangkan menurut penelitian Stamford (1995) mengungkapkan bahwa olahraga dapat menurunkan tekanan sistolik maupun diastolik pada orang yang mempunyai tekanan darah tinggi tingkat ringan.

Menurut data yang didapatkan dari petugas di Puskesmas DTP Jatinangor terdapat data bahwa lansia di wilayah kerja puskesmas Jatinangor berjumlah 5034 jiwa dan sasaran pra lansia berjumlah 8524 jiwa, didapatkan data bahwa kasus tekanan darah tinggi menduduki pola penyakit terbanyak pertama pada lansia dengan jumlah lansia yang datang berkunjung berdasarkan data 5 bulan terakhir yaitu dari bulan November 2014 sampai dengan Maret 2015 berjumlah 1564 pasien atau rata-rata 313 pasien per bulan.

Dari hasil wawancara kepada 10 orang lansia yang sudah rutin mengikuti senam jantung sehat mengatakan 7 lansia mempunyai tekanan darah yang tetap tinggi tetapi stabil dengan nilai tekanan darah $140 / 90 \mathrm{mmHg}$ sampai $180 / 120 \mathrm{mmHg}$, dan mereka masih sering mengeluh pusing, kepala terasa berat, sakit dan kaku pada persendian tangan dan kaki.

Hal yang sama dikeluhkan juga oleh lansia hipertensi yang belum lama mengikuti senam jantung sehat. Adapun lansia hipertensi yang sudah rutin mengikuti senam jantung sehat mengatakan bahwa mengalami penurunan tekanan darah sebanyak 3 orang.

Atas dasar fenomena tersebut, maka penulis merasa tertarik untuk melakukan penelitian dengan judul Pengaruh Senam Jantung Sehat Terhadap Nilai Tekanan Darah Pada Lansia Penderita Hipertensi di Puskesmas DTP Jatinangor.

\section{METODE}

Jenis penelitian dalam penelitian ini adalah quasi experiment atau eksperimen semu, dengan tujuan untuk mengetahui suatu gejala atau pengaruh yang timbul sebagai akibat dari adanya perlakuan. (Notoatmodjo, 2012). Pada penelitian ini peneliti akan melakukan penelitian mengenai pengaruh senam jantung sehat terhadap nilai tekanan darah pada lansia penderita hipertensi di Puskesmas DTP Jatinangor tahun 2015.

Populasi merupakan suatu subjek/ objek dengan karakteristik tertentu yang akan diteliti (Alimul, 2010). Populasi yang di pakai untuk penelitian ini adalah lansia yang menjadi peserta senam jantung sehat di posbindu binaan Puskesmas DTP Jatinangor sebanyak 125 responden. Besarnya jumlah sampel yang dibutuhkan pada penelitian ini dihitung berdasarkan uji perbedaan 2 proporsi (Sudigdo. 2011), Maka dapat diperoleh sampel pada penelitian ini sebesar 31 responden.

Instrumen pada penelitian ini ada dua yaitu alat-alat yang digunakan untuk mengukur tekanan darah berupa sphygmomanometer aneroid, stetoskop dan catatan observasi kemudian Instrument yang diperlukan untuk pelaksanaan senam jantung sehat yaitu instruksi senam jantung sehat dan pelatih yang sudah profesional dalam melatih senam jantung sehat.

Tahap pelaksanaan diantaranya : Mengidentifikasi lansia yang memenuhi kriteria inklusi dan eksklusi, menyampaikan informed consent, melakukan pengumpulan data tahap pertama (pretest) dengan melakukan pengukuran tekanan darah pada lansia 1 jam sebelum melakukan senam jantung sehat, melakukan intervensi atau perlakuan dengan melakukan senam jantung sehat seri I dengan durasi 22 menit 30 detik dan observasi partisipasif yaitu melakukan senam bersama para lansia, adapun langkah-langkah yang dilakukan dalam proses senam jantung sehat adalah tahap peregangan, latihan inti dan pendinginan. Kegiatan senam dilakukan sebanyak 3 kali dalam 1 minggu selama 3 minggu berturut-turut, melakukan pengukuran tekanan darah pada lansia 30 menit setelah mengikuti senam jantung sehat sebanyak 3 kali dalam 1 minggu. Setelah terkumpul dilakukan perhitungan nilai rata-rata tekanan darah. 
Pengolahan dan analisis data dilakukan dengan tahapan editing, processing dan cleaning. untuk mendeskripsikan karakteristik masing-masing variabel yang diteliti meliputi karakteristik responden dan tekanan darah dan analisa bivariate untuk melihat stabilitas tekanan darah awal, dengan setelah diberikan senam jantung sehat. Dari hasil uji normalitas data menunjukan nilai lebih besar dari 0,05 sehingga dapat disimpulkan data berdistribusi normal Berkaitan dengan hasil uji normalitas tersebut yang menyatakan data berdistribusi normal maka pada penelitian ini digunakan uji Paired T-Test.

Etika penelitian dengan menekankan prinsip-prinsip dalam etika yang berlaku, meliputi: lembar pesetujuan menjadi responden (Informed Consent), tanpa nama (Anonimity), kerahasiaan (Confidentiality) dan keamanan (privacy).

\section{HASIL}

\section{Karakteristik Responden}

Tabel 1. Karakteristik Lansia Penderita Hipertensi Yang Mengikuti Senam Jantung Sehat Di Puskesmas DTP Jatinangor

\begin{tabular}{|c|c|c|}
\hline Kategori & Frekuensi & $\%$ \\
\hline $\begin{array}{c}\text { Usia : } \\
46-55 \text { tahun } \\
56-65 \text { tahun } \\
>65 \text { tahun }\end{array}$ & $\begin{array}{c}12 \\
11 \\
1\end{array}$ & $\begin{array}{c}50 \\
45,8 \\
4,2\end{array}$ \\
\hline Jumlah & 24 & 100 \\
\hline $\begin{array}{c}\text { Jenis Kelamin : } \\
\text { Perempuan } \\
\text { Laki-Laki }\end{array}$ & $\begin{array}{c}24 \\
-\end{array}$ & $\begin{array}{c}100 \\
-\end{array}$ \\
\hline Jumlah & 24 & 100 \\
\hline $\begin{array}{c}\text { Pendidikan : } \\
\text { SD } \\
\text { SMP } \\
\text { SMA } \\
\text { D3 } \\
\text { Jumlah }\end{array}$ & $\begin{array}{c}13 \\
5 \\
5 \\
1 \\
24\end{array}$ & $\begin{array}{c}54,2 \\
20,8 \\
20,8 \\
4,2 \\
100\end{array}$ \\
\hline $\begin{array}{c}\text { Penyakit Lain } \\
\text { Yang Di Derita : } \\
\text { Tidak Ada Penyakit } \\
\text { Arthritis } \\
\text { Gastritis } \\
\text { Asma } \\
\text { Diabetes }\end{array}$ & $\begin{array}{c}11 \\
6 \\
5 \\
1 \\
1\end{array}$ & $\begin{array}{c}45,8 \\
25 \\
20,8 \\
4,2 \\
4,2\end{array}$ \\
\hline Jumlah & 24 & 100 \\
\hline
\end{tabular}

\section{Analisis Univariat}

Tabel 2. Nilai Rata-Rata Tekanan Darah Sistolik Pada Lansia Penderita Hipertensi Di Puskesmas DTP Jatinangor

\begin{tabular}{clc}
\hline $\begin{array}{c}\text { Pengukuran Tekanan Darah } \\
\text { Sistolik }\end{array}$ & Rata-Rata Sistolik (mmHg) & Standar Deviasi \\
\hline Minggu I & Pretest : 152,1 & 12,6 \\
\cline { 2 - 3 } & Posttest : 138,8 & 12,7 \\
\hline
\end{tabular}




\begin{tabular}{clc}
\hline \multirow{2}{*}{ Minggu II } & Pretest : 142,3 & 13,1 \\
\cline { 2 - 3 } & Posttest : 128,3 & 11,1 \\
\hline \multirow{2}{*}{ Minggu III } & Pretest : 131,7 & 9,2 \\
\cline { 2 - 3 } & Posttest : 121,6 & 9,4 \\
\hline \multirow{2}{*}{ Selama III Minggu } & Pretest : 142,8 & 10,6 \\
\cline { 2 - 3 } & Posttest : 129,6 & 9,2 \\
\hline
\end{tabular}

Tabel 3. Nilai Rata-Rata Tekanan Darah Diastolik Pada Lansia Penderita Hipertensi Di Puskesmas DTP Jatinangor

\begin{tabular}{clc}
\hline Pengukuran Tekanan Darah Diastolik & Rata-Rata Diastolik (mmHg) & Standar Deviasi \\
\hline \multirow{2}{*}{ Minggu I } & Pretest : 102,1 & 9,9 \\
\cline { 2 - 3 } & Posttest $: 91,7$ & 7,5 \\
\hline \multirow{2}{*}{ Minggu II } & Pretest $: 94,2$ & 8,6 \\
\cline { 2 - 3 } & Posttest $: 85,0$ & 6,5 \\
\hline \multirow{2}{*}{ Minggu III } & Pretest $: 86,3$ & 6,3 \\
\cline { 2 - 3 } & Posttest $: 82,1$ & 7,6 \\
\hline \multirow{2}{*}{ Selama III Minggu } & Pretest : 94,2 & 6,0 \\
\cline { 2 - 3 } & Posttest $: 86,3$ & 5,1 \\
\hline
\end{tabular}

\section{Analisa Bivariat}

Tabel 4. Pengaruh Senam Jantung Sehat Terhadap Nilai Tekanan Darah Sebelum Dan Sesudah Senam Jantung Sehat Di Puskesmas DTP Jatinangor

\begin{tabular}{|c|c|c|c|c|}
\hline Variabel & $\begin{array}{c}\text { Mean } \\
(\mathrm{mmHg})\end{array}$ & $\begin{array}{l}\text { Standar } \\
\text { Deviasi }\end{array}$ & $\mathbf{t}$ & p-Value \\
\hline \multirow{2}{*}{ Nilai sistolik } & Pretest :142,8 & 10,6 & 13,193 & 0,000 \\
\hline & Posttest :129,6 & 9,2 & & \\
\hline \multirow[b]{2}{*}{ Nilai Diastolik } & Pretest : 94,2 & 6,0 & 8,258 & 0,000 \\
\hline & Posttest : 86,3 & 5,1 & & \\
\hline
\end{tabular}

\section{PEMBAHASAN}

Berdasarkan hasil penelitian, maka dapat dilihat hasil dari nilai rata-rata tekanan darah sistolik selama 3 minggu pada lansia penderita hipertensi sebelum dilakukannya senam jantung sehat (pretest) adalah 142,8 $\mathrm{mmHg}$ dan setelah dilakukannya senam jantung sehat (posttest), nilai ratarata tekanan darah sistolik pada lansia penderita hipertensi adalah 129,6 mmHg.

Dilihat dari nilai rata-rata tekanan darah sistolik pada lansia penderita hipertensi sebelum dan sesudah dilakukan senam jantung sehat terlihat adanya penurunan tekanan darah sebesar 13,2 $\mathrm{mmHg}$, hal ini menujukan bahwa dengan melakukan gerakan olahraga yang tepat selama 22 menit 30 detik dan dilakukan sebanyak 3 kali per minggu, selama 3 minggu dapat menurunkan tekanan darah. Hal ini sesuai dengan teori Divine (2012) yaitu untuk melihat respon tekanan darah yang terjadi selama berolahraga rutin, olahraga selama 30 menit secara rutin, 3 kali seminggu seharusnya menjadi tujuan minimum untuk melihat adanya respon tekanan darah. (Divine, 2012)

Berdasarkan hasil penelitian, maka dapat dilihat hasil dari nilai rata-rata tekanan darah diastolic selama 3 minggu pada lansia penderita hipertensi sebelum dilakukannya senam jantung sehat (pretest) adalah $94,2 \mathrm{mmHg}$ dan rata-rata setelah dilakukan senam jantung sehat (posttest) adalah $86,3 \mathrm{mmHg}$. Dilihat dari selisih nilai rata-rata tekanan darah diastolic pada lansia penderita hipertensi sebelum dan sesudah dilakukannya senam jantung sehat menunjukan adanya penurunan tekanan darah sebesar 7,9 mmHg, hal ini menunjukan adanya penurunan. 
Selain itu dilihat dari hasil statistic, secara klinis pengaruh senam jantung sehat terhadap nilai tekanan darah sistolik dan diastolik terbukti ada pengaruh yaitu dengan melihat nilai rata-rata tekanan darah sistolik lansia penderita hipertensi sebelum dan sesudah senam jantung sehat yang mengalami penurunan dari $142,8 \mathrm{mmHg}$ (pretest) menjadi $129,6 \mathrm{mmHg}$ (posttest) dan nilai rata-rata tekanan darah diastolik lansia penderita hipertensi sebelum dan sesudah senam jantung sehat yang mengalami penurunan dari $94,2 \mathrm{mmHg}$ (pretest) menjadi $86,3 \mathrm{mmHg}$ (posttest).

Berdasarkan hasil uji statistic untuk pengaruh senam jantung sehat terhadap nilai tekanakan darah sistolik dan diastolik dengan uji Paired T-Test, diperoleh nilai significant sig.(2tailed) : 0,000< nilai a $(0,05)$, sehingga dapat disimpulkan $\mathrm{H}_{-} 0$ ditolak dan Ha diterima yang artinya ada pengaruh senam jantung sehat terhadap nilai tekanan darah sistolik dan diastolic pada lansia penderita hipertensi. Adanya pengaruh senam jantung sehat terhadap nilai tekanan darah sistolik didukung dengan hasil pengukuran tekanan darah terhadap lansia, dilihat dari hasilnya dapat dikatakan jenis hipertensi yang diderita lansia kebanyakan adalah hipertensi ringan sehingga dengan melakukan senam jantung sehat secara teratur 3 kali dalam seminggu selama 22 menit 30 detik akan menyebabkan tahanan perifer menurun yang selanjutnya akan menurunkan tekanan darah.

Menurut Martha dkk. (1995), olahraga dapat menurunkan tekanan darah. Hal ini didukung oleh hasil penelitian yang dilakukan oleh Werdhani (2005) dengan judul "Hubungan Frekuensi Dan Keteraturan Senam Terhadap Penurunan Tekanan Darah Pada Anggota Klub Jantung Sehat Pondalisa. Hasilnya menunjukan terdapat penurunan tekanan darah pada $32,58 \%$ anggota dengan rata-rata penurunan tekanan darah sistolik diastolik sebesar $6 \mathrm{mmHg} / 4 \mathrm{mmHg}$ yang dapat dipertahankan minimal selama 1 bulan.

Hal ini sesuai dengan teori bahwa terapi hipertensi untuk mengontrol tekanan darah selain dengan obat-obatan dapat dilakukan dengan terapi nonfarmakologi yaitu dengan pola hidup sehat, salah satunya dengan melakukan olahraga rutin dan teratur (Sani, 2007).

\section{KESIMPULAN}

Sebelum dilakukan senam jantung sehat, nilai rata-rata tekanan darah sistolik pada lansia penderita hipertensi $142,8 \mathrm{mmHg}$ dan nilai rata-rata tekanan darah diastolic $94,2 \mathrm{mmHg}$. Setelah dilakukan senam jantung sehat, nilai rata-rata tekanan darah sistolik pada lansia penderita hipertensi 129,6 $\mathrm{mmHg}$ dan nilai rata-rata tekanan darah diastolic $86,3 \mathrm{mmHg}$. Terdapat pengaruh senam jantung sehat terhadap nilai tekanan darah baik pada sistolik maupun diastolik pada lansia penderita hipertensi dengan nilai significant sig. (2tailed) $0,000<$ nilai $\alpha(0,05)$.

\section{DAFTAR PUSTAKA}

Anggriyana \& Atikah. (2010). Senam kesehatan. Yogyakarta: Muha Medika.

Azizah, M. Lilik. (2011). Keperawatan Lanjut Usia. Edisi 1. Yogyakarta: Graha Ilmu.

Cerika. (2008). Pengaruh Senam Jantung Sehat Seri I Terhadap Tekanan Darah. Pada Lansia http://digilib.unimed.ac.id/public/UNIMED-Undergraduate-28402-

8.\%20082266310016\%20BAB\%20I.pdf (28/12/2015 1:20 AM)

Darmojo, B.(2006). Buku Ajar Geriatri Ilmu Kesehatan Lanjut Usia, Edisi 3, Jakarta: Balai Penerbit FKUI.

Depkes RI (2009). Profil Kesehatan Indonesia. Jakarta: Departemen Republik Indonesia.

Divine, G. Jon. (2012). Program Olahraga tekanan Darah Tinggi. Klaten: PT Intan Sejati.

Ganong WF. (1995). Buku ajar fisiologi kedokteran, edisi 14. Penterjemah: Andrianto P. Jakarta: EGC Giri Wiarto. (2013). Fisiologi dan Olahraga. Yogyakarta: Graha Ilmu

Heti Sanajaya. (2014). Senam Jantung. http://hetisanjaya.blogspot.com/2014/05/senamjantung.html (26/4/2015 6:56 AM)

Irfan, A. (2007). National cardiovascular center harapan kita olahraga jantung sehat. ( 12/28 2014 1:19 AM). from http://www.pjnhk.go.id

Isgiyanto, A (2009), Teknik Pengambilan Sampel, Mitra Cendikia, Yogyakarta.

Katzung G.B. (2011). Farmakologi Dasar dan Klinik Edisi Pertama. Jakarta: Salemba Medika

Mariana, dkk. (2015). Pengaruh Senam Lansia Terhadap Stabilitas Tekanan Darah Pada Kelompok Lansia. http://ejournal.unsrat.ac.id/index.php/jkp/article/view/6697 (24/6/2015 4:28 PM)

Maryam, RS,dkk (2011). Mengenal lanjut usia dan perawatannya. Jakarta: Salemba Medika 
Notoatmodjo,S. (2010). Metodologi Penelitian Kesehatan. Edisi Revisi. Jakarta: Rineka Cipta Notoatmodjo,S. (2012). Metodologi Penelitian Kesehatan. Edisi Revisi. Jakarta: Rineka Cipta Pamudji Slamet. (2013). Mari Berpola Hidup Sehat. Jakarta: Pams Sarana Pintar

Price, A.S, dan Wilson, M, Lorrain. (2006). Patofisiologi Konsep Klinis Proses-Proses Penyakit Edisi 6 Vol I. Jakarta: EGC

Potter, P.A \& Perry, A.G. (2005). Buku ajar fundamental keperawatan konsep, proses, dan praktik. Alih Bahasa: Yasmin Asih. Edisi 4 Jakarta: EGC.

Potter, P.A \& Perry, A.G (2006). Fundamental Of Nursing: Concept, Theory and Praktice. Jakarta: Buku Kedokteran EGC.

Sani, Aulia. (2008). Hypertension. Jakarta: Medya Crea.

Santoso Mardi. (2008). Senam Diabetes Indonesia Seri 5. Yayasan Diabetes Indonesia: Jakarta.

Smeltzer and Bare, (2001). Fundamental Of Nursing. Jakarta: EGC

Sugiyono, (2012). Metode Penelitian Kuantitatif Kualitatif dan R \& D. Bandung: Alafbet.

Supriyadi.(2006). Motivasi Peserta Olahraga Senam Jantung Sehat di Klub Tri Lomba Juang Semarang Tahun 2006.

http://digilib.unnes.ac.id/gsdl/collect/skripsi/archives/HASH9fe0/e87ec964.dir/doc.pdf. $(12 / 28 / 20151: 25$ AM)

Susilo, Y. \& Wulandari, A. (2011). Cara jitu mengatasi hipertensi. Edisi 1. Yogyakarta: ANDI.

Sustrani, L. (2006). Hipertensi. Jakarta: Gramedia Pustaka Utama

Tita Rosita. (2012). Pengaruh Senam Jantung Sehat Terhadap Nilai Tekanan Darah Pada Lansia Di BPSTW Pakutandang Ciparay

Wajan Udjianto. (2011). Keperawatan Kardiovaskuler. Jakarta: Salemba Medika

Yudik Prasetyo. Olahraga Bagi $\quad$ Penderita Hipertensi http://staff.uny.ac.id/sites/default/files/132308484/Olahraga_Bagi_Penderita_Hipertensi.pdf $(12 / 28 / 2015$ 1:19 AM) 